\title{
Two new species of freshwater crabs from the highlands of northern Uganda, East Africa and a redescription of Potamonautes amalerensis (Rathbun, 1935) stat. rev. from Mount Kadam (Brachyura: Potamoidea: Potamonautidae)
}

\author{
Neil CUMBERLIDGE ${ }^{1, *} \&$ Paul F. CLARK ${ }^{2}$ \\ ${ }^{1}$ Department of Biology, Northern Michigan University, Marquette, MI, USA. \\ ${ }^{2}$ Department of Life Sciences, The Natural History Museum, Cromwell Road, London, SW7 5BD, UK. \\ *Corresponding author: ncumberl@nmu.edu \\ 2E-mail: p.clark@nhm.ac.uk \\ ${ }^{1}$ urn:1sid:zoobank.org:author:05F6365E-D168-4AE3-B511-80FA7E31ACC1 \\ 2 urn:lsid:zoobank.org:author:BB4A2E90-621A-40BB-A90C-FFDCEE71A4E9
}

\begin{abstract}
Two new species of potamonautid freshwater crabs are described from the Imatong Mountains and Mount Moroto in northern Uganda, East Africa, and a third highland species, Potamonautes amalerensis (Rathbun, 1935) stat. rev. from Mount Kadam is re-diagnosed based on examination of the holotype. All three species are endemic to a different mountain range and their collection localities indicate a distinct preference for higher altitudes. Diagnoses, illustrations and distribution maps are provided for these taxa, and they are compared to similar species from the region. The conservation status of all three species is discussed.
\end{abstract}

Key words. Potamonautes imatongensis sp. nov., Potamonautes morotoensis sp. nov., Imatong Mountains, Mount Moroto, Mount Kadam.

Cumberlidge N. \& Clark P.F. 2016. Two new species of freshwater crabs from the highlands of northern Uganda, East Africa and a redescription of Potamonautes amalerensis (Rathbun, 1935) stat. rev. from Mount Kadam (Brachyura: Potamoidea: Potamonautidae). European Journal of Taxonomy 182: 1-18. http://dx.doi.org/10.5852/ejt.2106.182

\section{Introduction}

Freshwater crabs from the highland regions of northern Uganda collected by Trefor R. Williams (formerly University of Liverpool, United Kingdom) and his colleagues in the 1960s were made available to the authors for examination. This material proved to include two new species that are described here based on a unique combination of adult male characters including the first gonopod, carapace, thoracic sternum and chelipeds. The two new species were collected from streams and rivers draining the slopes of mountain ranges in the Acholi and Karamajo Provinces of northern Uganda during a survey aimed at a better understanding of the transmission of river blindness (Onchocerciasis) to humans (Barnley \& Prentice 1958; McMahon et al. 1958; Hynes et al. 1961; Williams et al. 1964; Williams 1968, 1991; 
Crosskey 1990). The third species, Potamon (Geothelphusa) amalerensis Rathbun, 1935 stat. rev., is from Mount Kadam in the Karamoja Province of Uganda and was collected by Arthur Loveridge during the American Natural History Museum Expedition to Kenya and Uganda in 1933-1934. This species is redescribed here as Potamonautes amalerensis (Rathbun, 1935) stat. rev. and a second locality is recorded.

Recently, Cumberlidge \& Clark (2010) reported on four species of freshwater crabs from Mount Elgon, a highland region in southeast Uganda, south of Mount Kadem, one of the highland ranges included in the present study. The freshwater crab faunas of Uganda's northern and eastern highlands include highaltitude taxa that are typically small-bodied restricted-range species that are endemic to their mountain ranges, despite the relatively close proximity of some of these localities.

All of the freshwater crabs reported on here belong to Potamonautes MacLeay, 1838. Specimens of the two new species are deposited in the NHM, London, UK, while the holotype and paratypes of P. amalerensis stat. rev. are registered in the MCZ, Harvard University, Cambridge, MA, U.S.A. The re-description of $P$. amalerensis stat. rev. is based on examination of the type material and is necessary because it is still difficult for the non-specialist to distinguish between the many Potamonautes species from Uganda. This is due to an absence of modern taxonomic treatments, not least because the only available identification keys (Rathbun 1921; Chace 1942; Bott 1955) are insufficient by modern standards and their systematics is dated. At present, the only way to make reliable identifications of freshwater crabs from this part of Africa is to refer to the original type series of all relevant taxa but these are held in different European and North American museums. Unfortunately, molecular data for the three species reported on here are not available, because all of this material was originally preserved in formalin. Diagnoses, illustrations, and distribution maps are provided for these taxa, and they are compared to similar species from the region. The conservation status of all three species is discussed. The addition of $P$. imatongensis sp. nov. and $P$. morotoensis sp. nov., and the recognition of a previously suppressed taxon, $P$. amalerensis stat. rev. raises to 13 the number of freshwater crabs known from Uganda (Cumberlidge \& Clark 2010).

\section{Material and methods}

Measurements were made with digital calipers and are given in millimeters. The terminology is adapted from Cumberlidge (1999) and the higher classification used here follows that of $\mathrm{Ng}$ et al. (2008). Line drawings were prepared using a Leica MZ 16 binocular microscope. The habitus photographs were taken with a digital camera in combination with a Leiz MZ 95 adapter. Post processing was undertaken using Adobe Photoshop CS5.

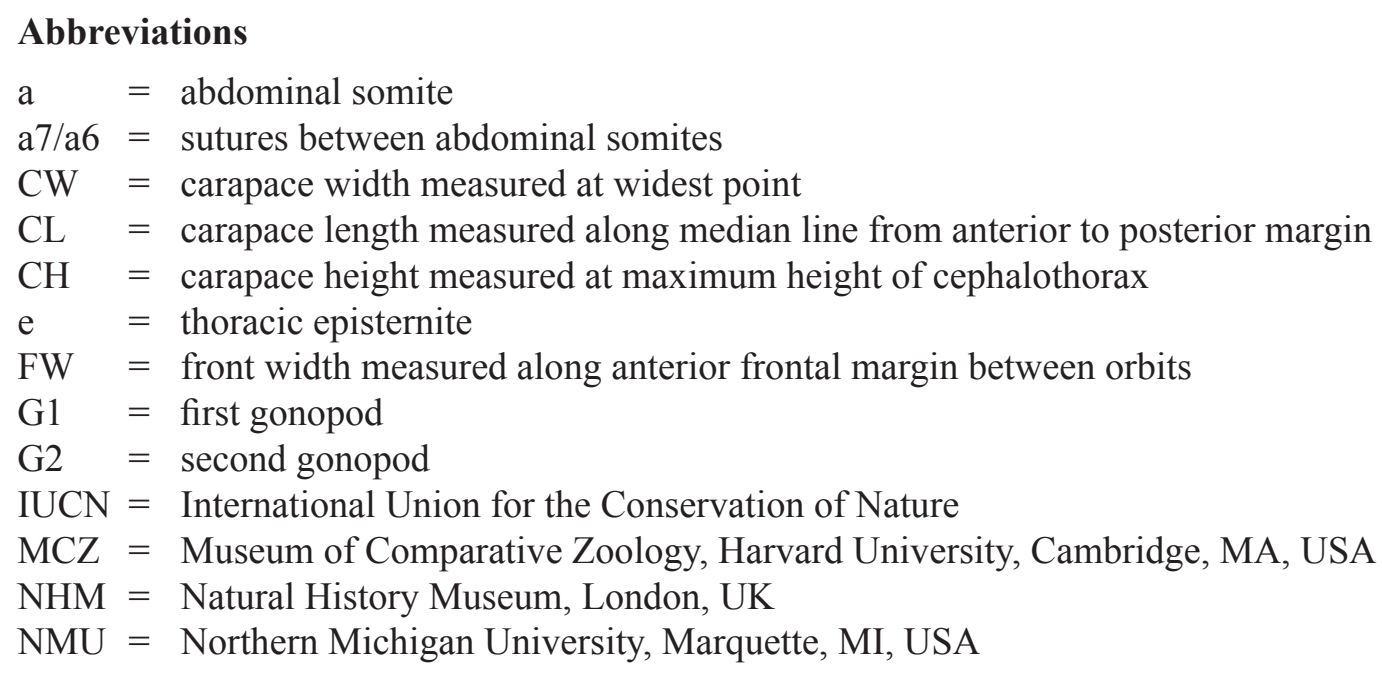




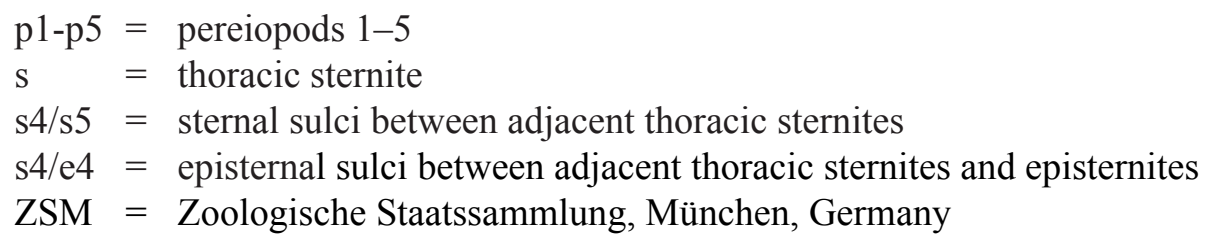

\title{
Results
}

\author{
Infraorder Brachyura Latreille, 1802 \\ Superfamily Potamoidea Ortmann, 1896 \\ Family Potamonautidae Bott, 1970 \\ Subfamily Potamonautinae Bott, 1970 \\ Genus Potamonautes MacLeay, 1838
}

Potamonautes imatongensis sp. nov. urn:lsid:zoobank.org:act:3FEF2D5C-9660-4C99-AC96-E9DEE74E1412

Figs 1A-B; 2A-B, G, J; 3A-B, G-H; 4 A-C; 7A-B; 8

\section{Diagnosis}

Postfrontal crest faint but complete, lateral ends well defined, meeting epibranchial teeth; exorbital tooth low, blunt; epibranchial tooth reduced to granule; anterolateral margin posterior to epibranchial tooth smooth. Third maxilliped ischium lacking vertical groove. Sternal sulcus s3/s4 deep at edges, faint medially, almost meeting thickened, raised anterior margin of sternoabdominal cavity; margins of s4 distinctly raised, thickened. Fixed finger (propodus), movable finger (dactylus) of major cheliped of adult male both slim, elongated, lined by small teeth; movable finger (dactylus) highly arched, enclosing oval interspace when closed. Cheliped carpus: first tooth medium sized, pointed; second tooth small, broad, pointed. G1 terminal article short, straight, in line with longitudinal axis, cone-shaped, evenly tapering, tip narrow, tube-like.

\section{Etymology}

The new species is named for the Imatong Mountains on the border between Uganda and South Sudan, which is the locality where this species was first collected.

\section{Material examined}

\section{Holotype}

UGANDA: adult $\hat{\jmath}$, CW 21.5, CL 14.4, CH 7.4, FW $6.5 \mathrm{~mm}$, Imatong Mountains, near border with South Sudan $\left(3.79^{\circ} \mathrm{N}, 32.87^{\circ} \mathrm{E}\right)$, at 2,134 m asl, 11 Aug. 1955, L.C. Beadle (NHM 1955.11.8.26-27).

\section{Paratypes}


River, northern Acholi District (3.74 $\left.\mathrm{N}, 32.90^{\circ} \mathrm{E}\right)$, at 1,173 m asl, 11 Aug. 1955, L. C. Beadle (NHM 1955.11.8.20-25).

\section{Other material examined}

UGANDA: adult $\partial^{\lambda}$, CW 21.5, CL 14.7, CH 7.7, FW $6.5 \mathrm{~mm}$ (NHM 2016.16); 5 adult ${ }^{\lambda}{ }^{\lambda}$, CWs 20.0, 18.0, 19.2, 21.2, 21.3 (NHMUK 2016.17-21); 4 adult 웅, CWs 23.1, 19.4, 18.2, $19.2 \mathrm{~mm}$ (NHMUK 2016.22-25), 2 juveniles CW 12.1, 13.0 mm (NHMUK 2016. 26-27), tributary of the Aringa River at Lututuru (48 km north of Kitgum), Imatong Mountains, northern Acholi District near border with South Sudan $\left(3.75^{\circ} \mathrm{N}, 32.90^{\circ} \mathrm{E}\right)$, at $1,524 \mathrm{~m}$ asl, $22.5^{\circ} \mathrm{C}$, at 4:00 pm, 16 May 1968, A.W.R. McRae (NMU TRW 1968.03); adult ${ }^{\lambda}$, CW 21.5, CL 14.4, CH 7.4, FW 6.5 mm, Aringa River, northern Acholi District $\left(3.74^{\circ} \mathrm{N}, 32.90^{\circ} \mathrm{E}\right), 1,173 \mathrm{~m}$ asl, 11 Aug. 1955, L. C. Beadle (NHM 1955.11.8.20-25). 


\section{Type locality}

Uganda, Imatong Mountains, near border with South Sudan $\left(3.79^{\circ} \mathrm{N}, 32.87^{\circ} \mathrm{E}\right)$, at an altitude of $2,134 \mathrm{~m}$ asl.

\section{Description}

Based on holotype (adult male CW 21.5). Carapace outline transversely oval, medium height (CH/FW 1.1); front broad, measuring one-third CW (FW/CW 0.30). Postfrontal crest faint but complete, lateral ends well defined, meeting epibranchial teeth; epigastric crests clear, median sulcus between crests short, forked posteriorly, semi-circular, urogastric, cardiac, posterior, cervical carapace grooves all distinct. Exorbital tooth low, blunt; epibranchial tooth reduced to granule; anterolateral margin posterior to epibranchial tooth smooth; anterolateral margin between exorbital, epibranchial teeth smooth, curving slightly outward, lacking intermediate tooth; carapace sidewall vertical sulcus faint, incomplete,

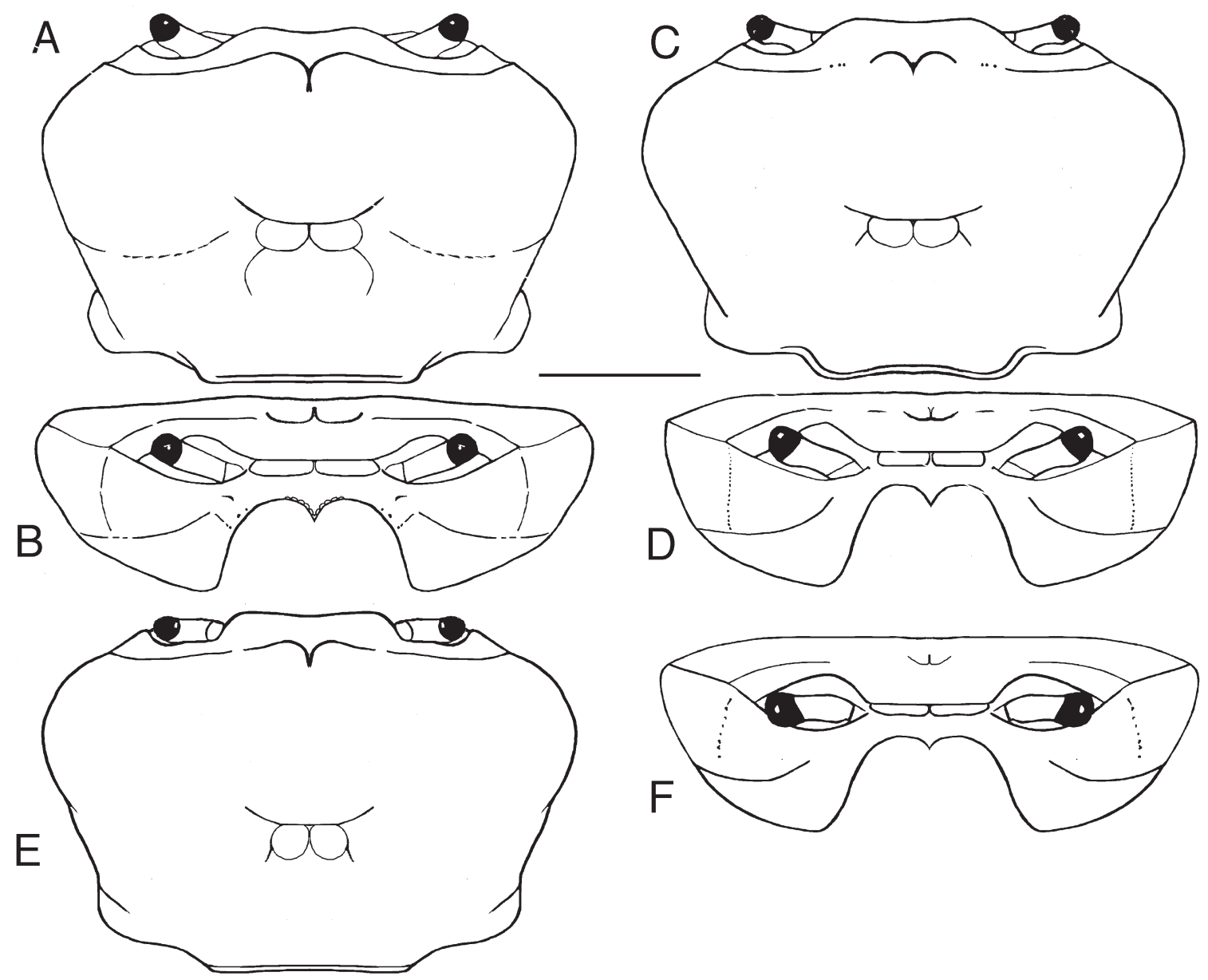

Fig. 1. A-B. Potamonautes imatongensis sp. nov., holotype, adult $\partial^{\lambda}, \mathrm{CW} 21.5 \mathrm{~mm}$, from the Imatong Mountains in northern Uganda (NHM 1955.11.8.26-27). A. Carapace, dorsal view. B. Carapace, frontal view. - C-D. Potamonautes morotoensis sp. nov., holotype, adult $\widehat{\jmath}$, CW $26 \mathrm{~mm}$, from Mount Moroto in northern Uganda (NHM 2015.3056). C. Carapace, dorsal view. D. Carapace, frontal view. E-F. Potamonautes amalerensis (Rathbun, 1935) stat. rev., holotype, adult $\widehat{\jmath}$, CW $31.5 \mathrm{~mm}$, from Mount Kadam, northern Uganda (MCZ 8238). E. Carapace, dorsal view. F. Carapace, frontal view. Scale bar: A-B $=6.3 \mathrm{~mm} ; \mathrm{C}-\mathrm{D}=7.3 \mathrm{~mm} ; \mathrm{E}-\mathrm{F}=9.1 \mathrm{~mm}$. 

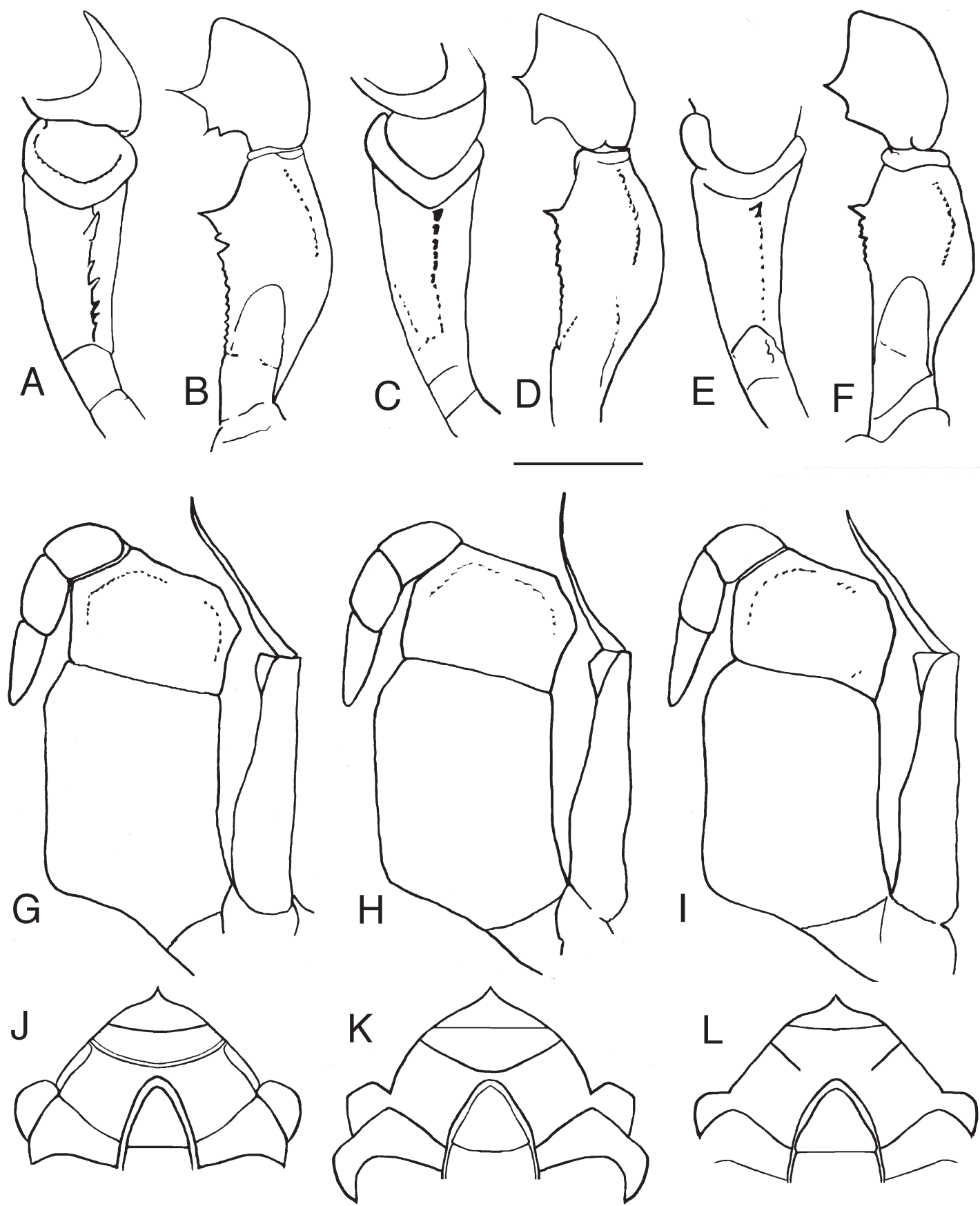

Fig. 2. A-B, G, J. Potamonautes imatongensis sp. nov., holotype, adult $\widehat{\partial}$, CW $21.5 \mathrm{~mm}$, from the Imatong Mountains in northern Uganda (NHM 1955.11.8.26-27). A. Carpus and merus of right cheliped, dorsal view. B. Carpus and merus of right cheliped, ventral view. G. Third maxilliped frontal view. J. Anterior thoracic sternum. - C-D, H, K. Potamonautes morotoensis sp. nov., holotype, adult $\hat{o}$, CW 26 mm, from Mount Moroto in northern Uganda (NHM 2015.3056). C. Carpus and merus of right cheliped, dorsal view. D. Carpus and merus of right cheliped, ventral view. H. Third maxilliped, frontal view. K. Anterior thoracic sternum. - E-F, I, L. Potamonautes amalerensis (Rathbun, 1935) stat. rev., holotype, adult $\widehat{\jmath}$, CW $31.5 \mathrm{~mm}$, from Mount Kadam, northern Uganda (MCZ 8238). E. Carpus and merus of right cheliped, dorsal view. F. Carpus and merus of right cheliped, ventral view. I. Third maxilliped frontal view. $\mathbf{L}$. Anterior thoracic sternum. Scale bar: A-B $=3.4 \mathrm{~mm} ; \mathrm{C}-\mathrm{D}=3.8 \mathrm{~mm} ; \mathrm{E}-\mathrm{F}=$ $5.5 \mathrm{~mm} ; \mathrm{G}=4.6 \mathrm{~mm} ; \mathrm{H}=4.9 \mathrm{~mm} ; \mathrm{I}=7.8 \mathrm{~mm} ; \mathrm{J}=5.9 \mathrm{~mm} ; \mathrm{K}=7.3 \mathrm{~mm} ; \mathrm{L}=9.5 \mathrm{~mm}$. 

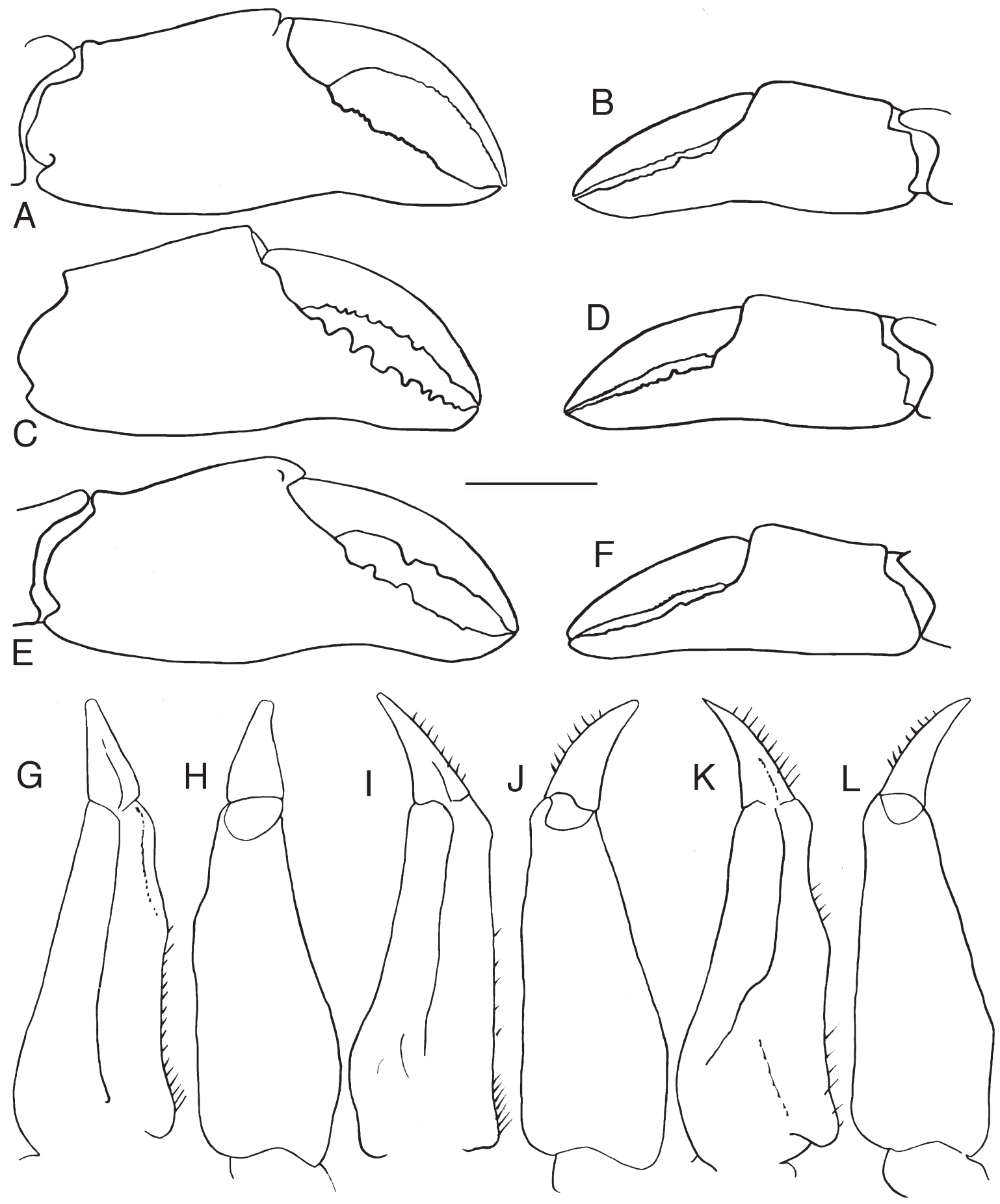

Fig. 3. A-B, G-H. Potamonautes imatongensis sp. nov., holotype, adult $\partial^{\lambda}, \mathrm{CW} 21.5 \mathrm{~mm}$, from the Imatong Mountains in northern Uganda (NHM 1955.11.8.26-27). A. Right cheliped, frontal view. B. Left cheliped, frontal view. G. G1 ventral view. H. G1 dorsal view. - C-D, I-J. Potamonautes

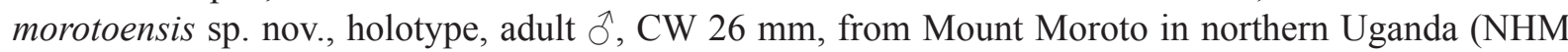
2015.3056). C. Right cheliped, frontal view. D. Left cheliped, frontal view. I. G1 ventral view. J. G1 dorsal view. - E-F, K-L. Potamonautes amalerensis (Rathbun, 1935) stat. rev., holotype, adult ô , CW $31.5 \mathrm{~mm}$, from Mount Kadam, northern Uganda (MCZ 8238). E. Right cheliped, frontal view. F. Left cheliped, frontal view. K. G1 ventral view. $\mathbf{L}$. G1 dorsal view. Scale bar: A-B $=6.8 \mathrm{~mm}$; $-\mathrm{D}=5.1 \mathrm{~mm}$; $\mathrm{E}-\mathrm{F}=6.5 \mathrm{~mm} ; \mathrm{G}-\mathrm{L}=4.5$. 
not meeting anterolateral margin. Suborbital margin smooth. Carapace sidewall pterygostomial region with distinct granulated vertical sulcus, ending at longitudinal sulcus, dividing sidewall into 3 parts. Third maxilliped exopod with long flagellum, ischium lacking vertical groove. Epistomial tooth large, triangular, edges lined by large rounded granules. Mandibular palp 2-segmented; terminal segment simple. Thoracic sternal sulcus $\mathrm{s} 2 / \mathrm{s} 3$ deep, running horizontally across sternum; thoracic sternal sulcus s3/s4 deep at edges, faint medially, almost meeting thickened, raised anterior margin of sternoabdominal cavity; margins of s4 distinctly raised, thickened. Thoracic episternal sulci s4/e4, s5/e5, s6/e6, s7/e7 all visible grooves. Chelipeds of adult male unequal; fixed (propodus) and movable (dactylus) fingers of adult male slim, elongated, both lined by small teeth, movable finger (dactylus) highly arched, enclosing oval interspace when closed. Cheliped carpus: first tooth medium size, pointed, second tooth small, broad, pointed. Inferior margins of merus of cheliped with series of small sharp teeth; distal meral tooth pointed; superior surface of merus granulated. Abdomen outline broadly triangular with straight edges. G1 terminal article short, straight, in line with longitudinal axis of gonopod, cone-shaped, evenly tapering, tip narrow, tube-like. G2 terminal article long, flagellum-like.

\section{Size}

Small species, adult size range $\mathrm{CW} 18.2-23 \mathrm{~mm}$.

\section{Colour}

Preserved specimens uniformly light brown.

\section{Distribution}

The localities where this species is known to occur are in the Aringa River or its tributaries in northern Acholi Province of Uganda close to the border with South Sudan. The Aringa River is part of the Nile River drainage and flows north out of Uganda, eventually meeting the White Nile River in South Sudan (Fig. 10). The third locality from the 'Sudan (now South Sudan)/Uganda border at 7,000 feet $(=2,134 \mathrm{~m}$ asl)' is vague, but has been estimated here based possible places at that altitude in the Aringa River basin in the Imatong Mountains.

\section{Ecology}

This species is so far known only from high altitude localities, and has been collected from streams at over 1,500 $\mathrm{m}$ asl, and in the Aringa River at 2,134 $\mathrm{m}$ asl.

\section{Vernacular name}

The Imatong Mountains Crab.

\section{Conservation status}

An IUCN conservation assessment of Potamonautes imatongensis sp. nov. has not yet been carried out.

\section{Remarks}

Potamonautes imatongensis sp. nov. is superficially similar to several other Potamonautes species that share the following characters: a small body size at maturity (beginning at $\mathrm{CW} 18 \mathrm{~mm}$ ), a complete postfrontal crest; completely reduced or absent exorbital and epibranchial teeth; smooth anterolateral margins immediately behind each epibranchial tooth; a third maxilliped ischium that lacks a visible sulcus; the first tooth on the carpus of the cheliped that is strong and pointed; a distal meral tooth of the cheliped that is strong and pointed; and a slim, elongated, highly arched dactylus of the male major cheliped. East African crabs that share this suite of characters include P. mutandensis (Chace, 1942) 

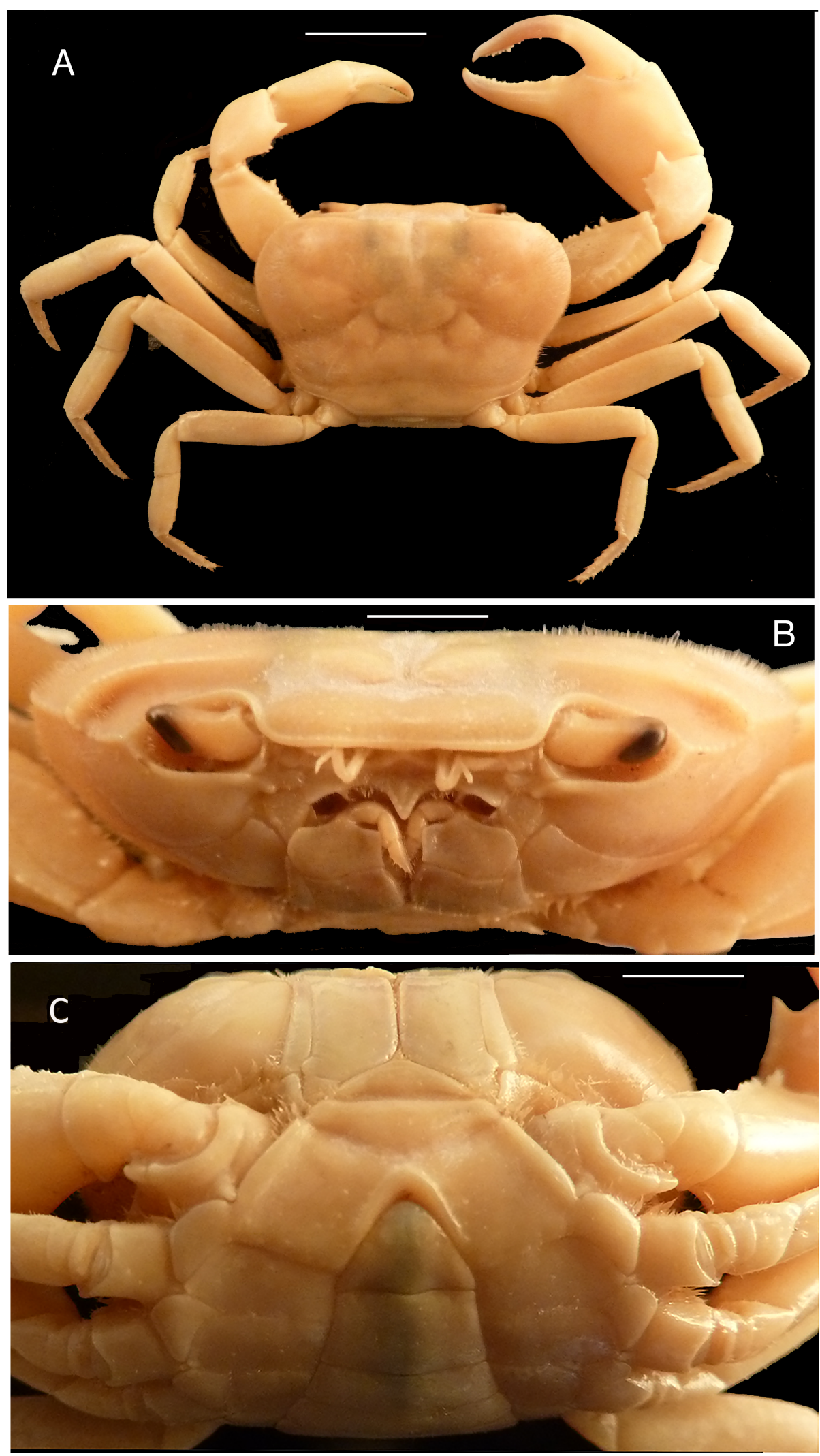

Fig. 4. Potamonautes imatongensis sp. nov., holotype, adult $\hat{0}, \mathrm{CW} 21.5 \mathrm{~mm}$, from the Imatong Mountains in northern Uganda (NHM 1955.11.8.26-27). A. Whole animal, dorsal view. B. Frontal view. C. Ventral view, anterior sternum. Scale bars: $21.4 \mathrm{~mm}$. 
(southwest Uganda), P. berardi (Audouin, 1826) (Nile River basin), P. williamsi Cumberlidge \& Clark, 2010 (Mount Elgon, Uganda), P. amalerensis (Rathbun, 1935) stat. rev. and P. morotoensis sp. nov.

Potamonautes imatongensis sp. nov. differs from P. mutandensis in that the second tooth on the carpus of the cheliped is weak, low and blunt (vs pointed and as large as the first carpal tooth in P. mutandensis), the outer margins of sternal segment s4 are distinctly thickened (vs slim and not thickened in P. mutandensis; see Chace 1942; Cumberlidge \& Meyer 2011), and the G1 terminal article of $P$. imatongensis sp. nov. is straight and cone-shaped and not directed only slightly outward (vs s-shaped, widened medially, and angled outward at a $45^{\circ}$ angle to the longitudinal axis of the gonopod in P. mutandensis).

Potamonautes imatongensis sp. nov. differs from P. berardi in that the G1 terminal article is straight, cone-shaped and not directed outward (vs straight at first, then bent sharply outward at $45^{\circ}$ to the longitudinal axis in the mid-section in $P$. berardi) and the outer margins of thoracic sternite $s 4$ are distinctly thickened (vs slender and not thickened in P. berardi; see Chace 1942; Cumberlidge \& Meyer 2011).

Potamonautes imatongensis sp. nov. differs from P. williamsi from Mount Elgon, Uganda, in that the first tooth on the carpus of the cheliped is strong and pointed (vs small and low in P. williamsi), thoracic sternal sulcus $\mathrm{s} 3 / \mathrm{s} 4$ is deep at the edges and medially faint (vs s3/s4 is reduced to two short notches on the external margins of the sternite in P. williamsi) and the outer margins of thoracic sternite $\mathrm{s} 4$ are distinctly thickened (vs slender and not thickened in P. williamsi; see Cumberlidge \& Clark 2010).

As for the species described here, P. imatongensis sp. nov. differs from P. morotoensis sp. nov. in that the G1 terminal article is straight, cone-shaped and tapering, with a long tube-like tip (vs straight at first, bent outward at $45^{\circ}$ to the longitudinal axis, and cone-shaped, tapering evenly to a down-turned tip in P. morotoensis sp. nov.), the first tooth on the carpus of the cheliped is medium sized and pointed, and the second carpal tooth is small, broad and pointed (vs both teeth small and low in P. morotoensis sp. nov.) and the dactylus of the cheliped is highly arched, enclosing a widely oval interspace when closed (vs a cheliped dactylus that is only slightly arched and enclosing a long narrow interspace when closed in P. morotoensis sp. nov.).

Potamonautes imatongensis sp. nov. differs from P. amalerensis stat. rev. in that the G1 terminal article is straight and cone-shaped with a long tube-like tip (vs straight at first, bent outward at $45^{\circ}$ to the longitudinal axis and cone-shaped, tapering evenly to a pointed tip in P. amalerensis stat. rev.), the first tooth on the carpus of the cheliped is medium sized and pointed, and the second carpal tooth is small, broad and pointed (vs a small first carpal tooth and reduced granule-sized second carpal tooth in P. amalerensis stat. rev.), and the dactylus of the cheliped is highly arched, enclosing a widely oval interspace when closed (vs a cheliped dactylus that is only slightly arched and encloses a long narrow interspace when closed in $P$. amalerensis stat. rev.).

Potamonautes morotoensis sp. nov. urn:Isid:zoobank.org:act:C751A933-6705-487F-9FEF-4584DC0DA4B7

Figs $1 \mathrm{C}-\mathrm{D} ; 2 \mathrm{C}-\mathrm{D}, \mathrm{H}, \mathrm{K} ; 3 \mathrm{C}-\mathrm{D}, \mathrm{I}-\mathrm{J} ; 5 \mathrm{~A}-\mathrm{C} ; 7 \mathrm{C}-\mathrm{D} ; 8$

\section{Diagnosis}

Based on holotype (adult male CW 26). Carapace outline transversely oval, medium height (CH/FW 1.0); exorbital tooth low, blunt, epibranchial tooth reduced to granule, postfrontal crest complete faint medially, lateral ends well defined meeting epibranchial teeth; anterolateral margin posterior to epibranchial tooth smooth; carapace sidewall vertical sulcus meeting anterolateral margin. Third maxilliped ischium lacking vertical groove. Sternal sulcus $\mathrm{s} 3 / \mathrm{s} 4$ deep, completely crossing sternum, meeting thickened, 

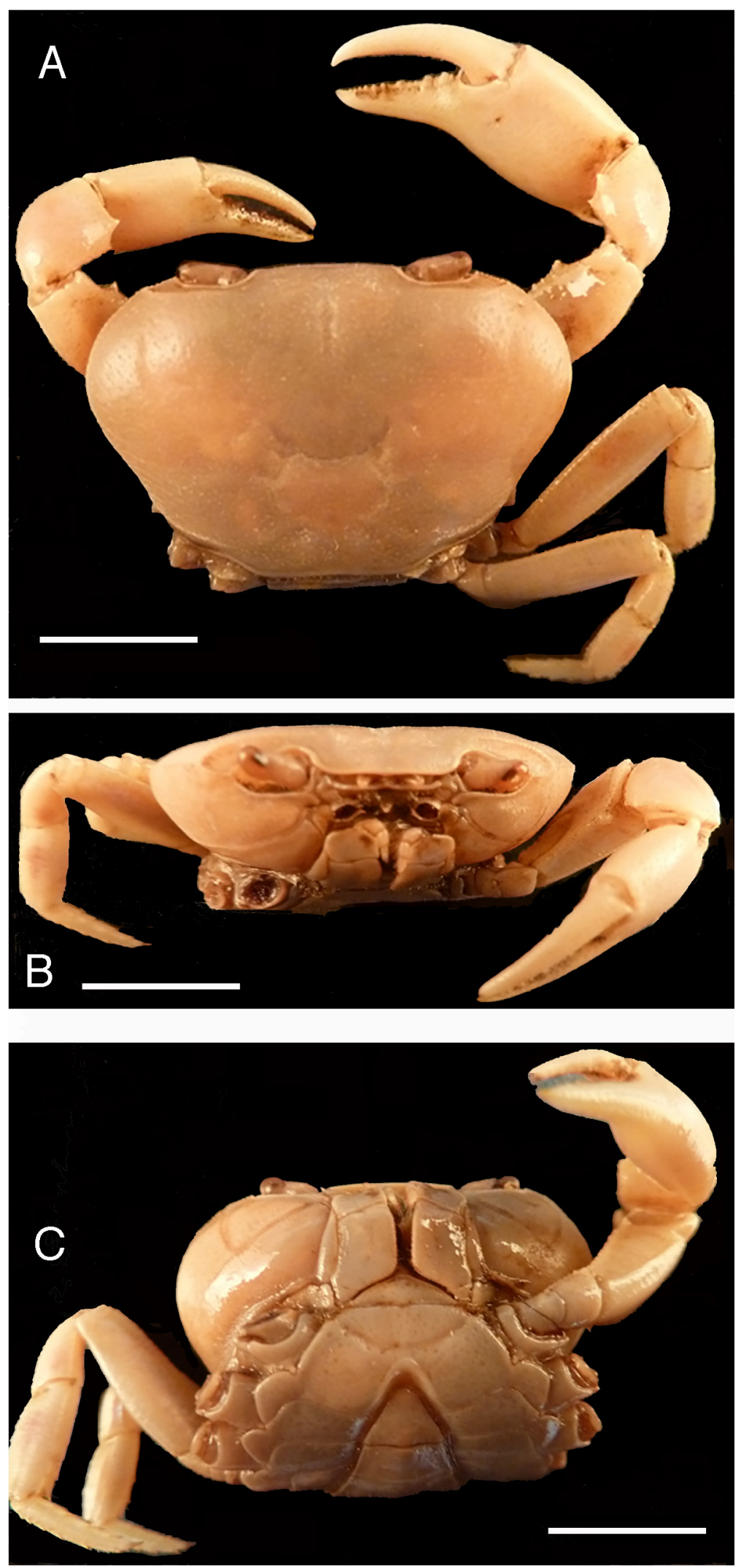

Fig. 5. Potamonautes morotoensis sp. nov., holotype, adult $\widehat{\partial}, \mathrm{CW} 26 \mathrm{~mm}$, from Mount Moroto in northern Uganda (NHM 2015.3056). A. Whole animal, dorsal view. B. Frontal view. C. Ventral view, anterior sternum. Scale bars: $21.4 \mathrm{~mm}$. 
raised anterior margin of sternoabdominal cavity; margins of s4 distinctly raised, thickened. Chelipeds of adult male unequal; movable finger (dactylus) and fixed finger (propodus) of major cheliped of adult male slim, elongated, fixed finger (propodus) with 2 large teeth proximally followed by series of small teeth; movable finger (dactylus) slightly arched, enclosing narrow rectangular interspace when closed. Inferior margins of merus of cheliped lined by series of small granules, distal meral tooth small pointed; superior surface of merus granulated. Cheliped carpus first and second teeth small, low, equal-sized. G1 terminal article short, straight, in line with longitudinal axis, cone-shaped, evenly tapering to pointed tip.

\section{Etymology}

The new species is named for Mount Moroto in Karamoja District, Uganda which is the only locality where this species has been collected.

\section{Material examined}

Holotype

UGANDA: adult $\widehat{\partial}$, CW 26, CL 17, CH 8.4, FW $8.4 \mathrm{~mm}$ (photographed), Lipath River, Mt. Moroto, near Matheniko Game Reserve, Karamoja District $\left(2.54^{\circ} \mathrm{N}, 34.73^{\circ} \mathrm{E}\right)$, extreme headwaters, about 2,438 $\mathrm{m}$ asl, in grassland, 9 Jul. 1963, T.R. Williams (NHM 2015.3056, formerly TRW collection 9 Jul.1963).

\section{Type locality}

Uganda, Lipath River, Mt. Moroto, near Matheniko Game Reserve, Karamoja District $\left(2.54^{\circ} \mathrm{N}\right.$, $34.73^{\circ} \mathrm{E}$ ), extreme headwaters, about $2,438 \mathrm{~m}$ asl, in grassland.

\section{Description}

Carapace medium height (CH/FW 1.0); front broad, measuring one-third CW (FW/CW 0.32). Semicircular, urogastric, cardiac, posterior, cervical carapace grooves all distinct. Postfrontal crest complete, faint medially, lateral ends well defined meeting epibranchial teeth; exorbital tooth low, blunt. Epigastric crests clear, median sulcus between crests short, forked posteriorly. Epibranchial tooth reduced to granule; anterolateral margin between exorbital, epibranchial teeth smooth, curving slightly outward, lacking intermediate tooth; anterolateral margin posterior to epibranchial tooth smooth; carapace sidewall vertical sulcus faint, incomplete, not meeting anterolateral margin. Suborbital margin smooth. Carapace sidewall with distinct granulated, vertical sulcus, ending at longitudinal sulcus, dividing sidewall into 3 parts. Third maxilliped exopod with long flagellum, ischium lacking vertical groove. Epistomial tooth large, triangular, edges lined by large round granules. Mandibular palp 2-segmented; terminal segment simple. Thoracic sternal sulcus s2/s3 deep, running horizontally across sternum; thoracic sternal sulcus s3/s4 deep at edges, faint in middle, almost meeting thickened, raised anterior margin of sternoabdominal cavity; margins of s4 distinctly raised, thickened. Thoracic episternal sulci s4/e4, s5/e5, s6/e6, s7/e 7 all visible grooves. Chelipeds of adult male unequal; movable finger (dactylus) and fixed finger (propodus) of major cheliped of adult male slim, elongated, propodus with 2 large teeth proximally followed by series of small teeth, dactylus slightly arched, enclosing narrow rectangular interspace when closed. Inferior margins of merus of cheliped with series of small granules, distal meral tooth small pointed; superior surface of merus granulated. Cheliped carpus first, second teeth small, low, equal-sized. Abdomen outline broadly triangular with straight edges. G1 terminal article short, straight, in line with longitudinal axis, cone-shaped, evenly tapering to broad tip. G2 terminal article long, flagellum-like.

\section{Size}

Small species, adult at CW $26 \mathrm{~mm}$. 


\section{Colour}

Preserved specimens uniformly light brown.

\section{Distribution}

Mount Moroto (2,438 m asl) in Karamoja Province, northern Uganda.

\section{Ecology}

This species is so far known only from a single high altitude locality, and was collected from a mountain stream at $2,438 \mathrm{~m}$ asl.

\section{Conservation status}

An IUCN conservation assessment of Potamonautes morotoensis sp. nov. has not yet been carried out, but given the fact that this species is known from a single specimen from a single locality it would probably be regarded as Data Deficient.

\section{Vernacular name}

Mount Moroto Crab

\section{Remarks}

Potamonautes morotoensis sp. nov. is superficially similar to several other Potamonautes species that share the following characters: a small body size at maturity, a complete postfrontal crest; completely reduced or absent exorbital and epibranchial teeth; smooth anterolateral margins immediately behind each epibranchial tooth; a third maxilliped ischium that lacks a visible sulcus; a first tooth on the carpus of the cheliped that is strong and pointed; a strong and pointed distal meral tooth; and a slim, elongated, highly arched dactylus of the cheliped. East African crabs that share these characters include Potamonautes imatongensis sp. nov., P. mutandensis (Chace, 1942) (southwest Uganda), P. berardi (Audouin, 1826) (Nile River basin), and P. williamsi Cumberlidge \& Clark, 2010 (Mount Elgon, Uganda).

Potamonautes morotoensis sp. nov. differs from P. amalerensis stat. rev. in that the second tooth on the carpus of the cheliped is small and low (vs the second carpal tooth is reduced to a granule in P. amalerensis stat. rev.) and the G1 terminal article tapers evenly to a broad tip (vs G1 terminal article tapering evenly to a pointed tip in P. amalerensis stat. rev.).

For comparisons of P. morotoensis sp. nov. with P. imatongensis sp. nov., see above.

Potamonautes amalerensis (Rathbun, 1935) stat. rev.

Figs 1E-F; 2E-F, I, L, 3E-F, K-L, 6A-C, 7E-F, 8

Potamon (Geothelphusa) amalerensis Rathbun, 1935: 25, pl. 2.

Potamonautes amalerensis $\mathrm{Ng}$ et al., 2008: 170 (in catalogue).

Potamon amalerensis - Chace 1942: 204, fig 8.

Potamonautes amalerensis - Cumberlidge et al. 2009, appendix 1: 894 (in list).

\section{Rediagnosis}

Carapace medium height $(\mathrm{CH} / \mathrm{FW} 1.1)$; exorbital tooth low, blunt, epibranchial tooth reduced to granule, postfrontal crest complete, faint medially, lateral ends well defined, meeting epibranchial teeth; anterolateral margin posterior to epibranchial tooth finely serrate, almost smooth; carapace sidewall vertical sulcus meeting anterolateral margin. Third maxilliped ischium lacking vertical groove. Sternal sulcus s3/s4 deep, completely crossing sternum, meeting thickened, raised anterior margin of 
CUMBERLIDGE N. \& CLARK P.F., New species of Ugandan freshwater crabs
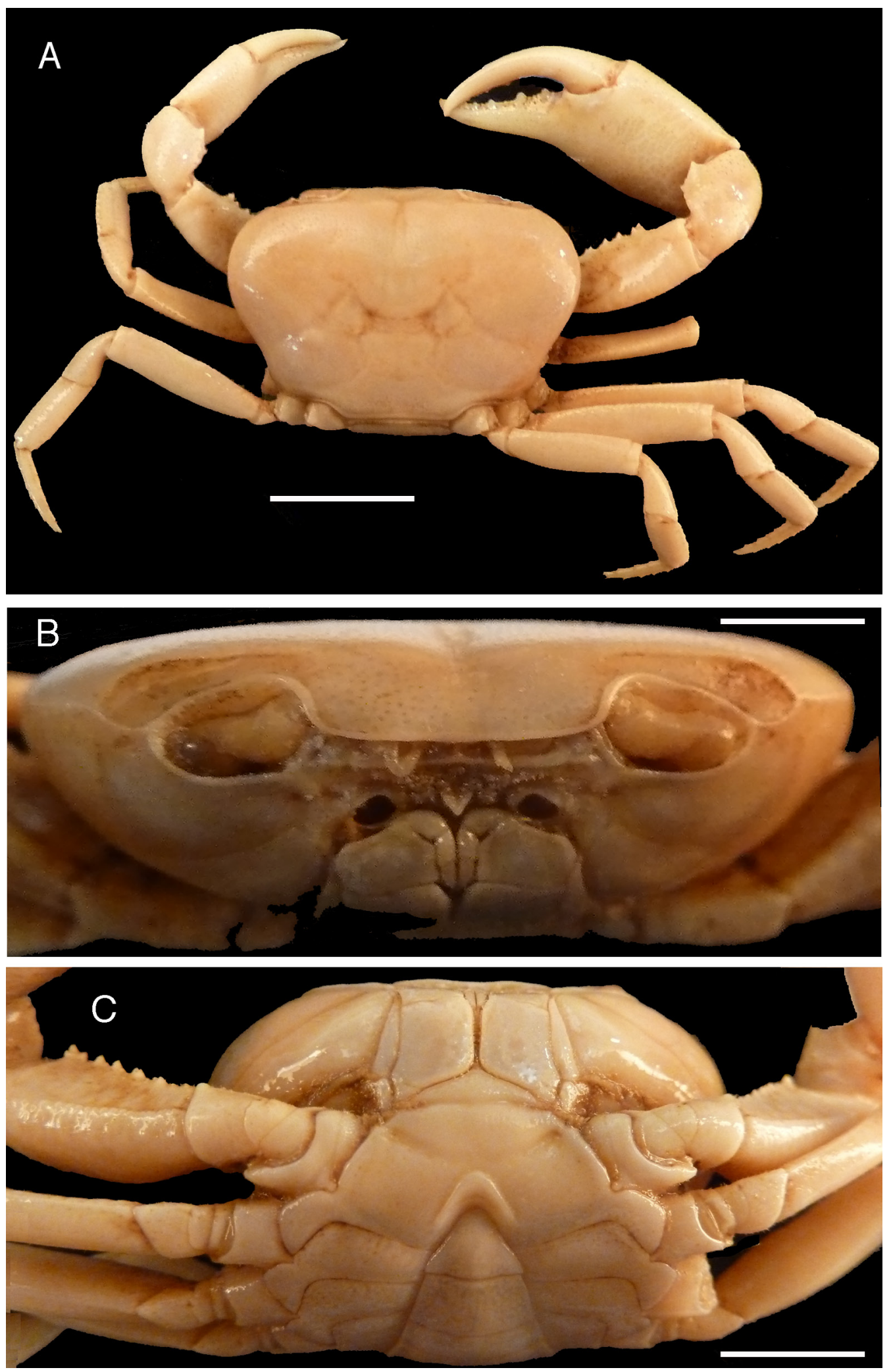

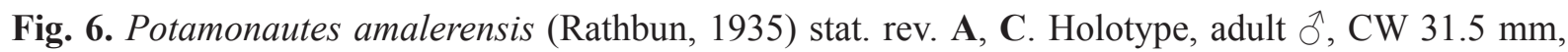
from Mount Kadam, northern Uganda (MCZ 8238). B. Adult $\hat{0}$, CW $31.5 \mathrm{~mm}$, from north side of Mt. Kadam northern Uganda (NMU TRW 1962.04). A. Whole animal, dorsal view. B. Frontal view. C. Ventral view, anterior sternum. Scale bars: $21.4 \mathrm{~mm}$. 
sternoabdominal cavity; margins of s4 distinctly raised, thickened. Inferior margins of merus of cheliped with series of small granules, distal meral tooth pointed; first cheliped carpal tooth small, second cheliped carpal tooth reduced to small granule. Fixed finger (propodus) and movable finger (dactylus) of major cheliped of adult male each with larger teeth interspersed with small teeth, dactylus slightly arched,
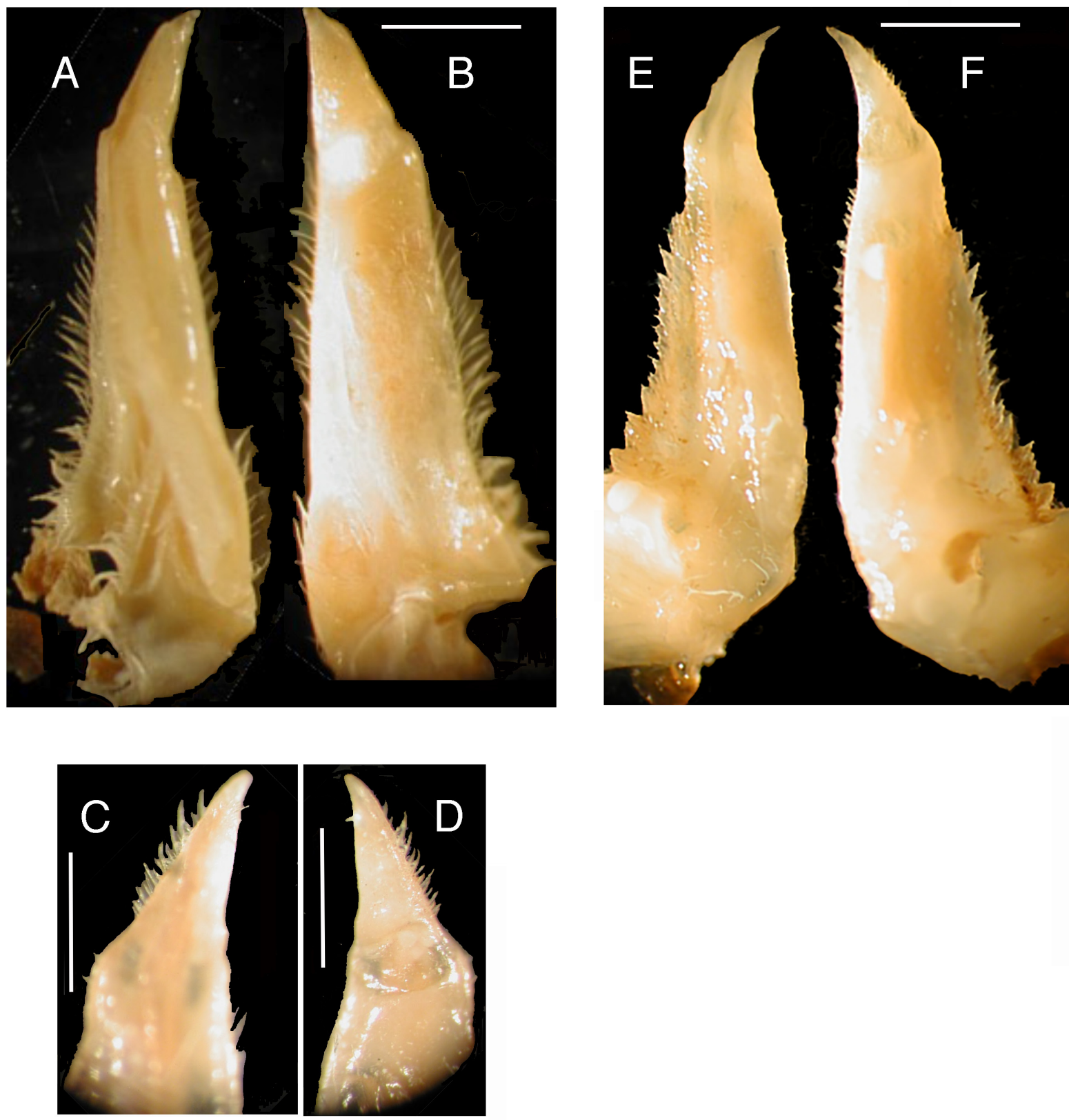

Fig. 7. A-B. Potamonautes imatongensis sp. nov., holotype, adult $\delta, \mathrm{CW} 21.5 \mathrm{~mm}$, from the Imatong Mountains in northern Uganda (NHM 1955.11.8.26-27). A. G1 ventral view. B. G1 dorsal view. C-D. Potamonautes morotoensis sp. nov., holotype, adult ${ }^{\top}, \mathrm{CW} 26 \mathrm{~mm}$, from Mount Moroto in northern Uganda (NHM 2015.3056). C. G1 ventral view. D. G1 dorsal view. - E-F. Potamonautes amalerensis (Rathbun, 1935) stat. rev., holotype, adult $\widehat{\jmath}$, CW $31.5 \mathrm{~mm}$, from Mount Kadam, northern Uganda (MCZ 8238). E. G1 terminal article ventral view. F. G1 terminal article dorsal view. Scale bars: $\mathrm{A}-\mathrm{B}=2.34 \mathrm{~mm}, \mathrm{C}-\mathrm{D}=3.1 \mathrm{~mm}, \mathrm{E}-\mathrm{F}=3.3 \mathrm{~mm}$. 
enclosing long narrow interspace when closed. G1 terminal article short cone-shaped, directed outward at $45^{\circ}$ angle to longitudinal axis of gonopod, evenly tapering to pointed tip.

\section{Material examined}

Holotype

UGANDA: adult $\widehat{\jmath}$, CW 26, CL 17.4, CH 8.4, FW 8.4 mm, Amaler River, Mt. Kadam (formerly Mt. Debasien), Karamoja District $\left(1.72^{\circ}\right.$ N, $34.72^{\circ}$ E), at 1,524 m asl, Sep. 1933, A. Loveridge (MCZ 8238).

\section{Paratypes}

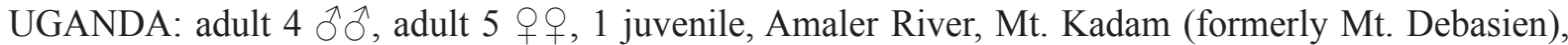
Karamoja District $\left(1.72^{\circ} \mathrm{N}, 34.72^{\circ} \mathrm{E}\right)$, at 1,524 m asl, Sep. 1933, A. Loveridge (MCZ 8237).

\section{Other material examined}

UGANDA: adult $\widehat{ }{ }^{\lambda}, \mathrm{CW} 31.5 \mathrm{~mm}$, north side of Mt. Kadam (formerly Mt. Debasien), Karamoja District $\left(1.81^{\circ} \mathrm{N}, 34.71^{\circ} \mathrm{E}\right)(\mathrm{NMU}$ TRW 1962.04$)$.

\section{Type locality}

Uganda, Amaler River, Mt. Kadam (formerly Mt. Debasien), Karamoja District (1.72 $\left.{ }^{\circ} \mathrm{N}, 34.72^{\circ} \mathrm{E}\right)$.

\section{Size}

Small species, adult size range between CW 26.0-31.5 mm.

\section{Colour}

Preserved specimens uniformly light brown.

\section{Distribution}

Uganda, Amaler River, Mt. Kadam (formerly Mt. Debasien), Karamoja District in Karamoja Province, northern Uganda. This species is known from only two localities: Amaler River $\left(1.72^{\circ} \mathrm{N}, 34.72^{\circ} \mathrm{E}\right)$, and the north side of Mt. Kadam $\left(1.81^{\circ} \mathrm{N}, 34.71^{\circ} \mathrm{E}\right)$.

\section{Ecology}

This species was collected from high altitude mountain streams at $1,524 \mathrm{~m}$ asl.

\section{Vernacular name}

Mount Kadam Crab.

\section{Conservation status}

This species is known only from two localities both on Mount Kadam in Uganda, and from a total of 11 specimens collected in 1935 and 1962. Potamonautes amalerensis stat. rev. was listed as Data Deficient (IUCN 2003; Cumberlidge et al. 2009) in view of the absence of further information on its extent of occurrence, ecological requirements, population size, population trends, and long-term threats (Cumberlidge 2008). The addition of a second locality on Mount Kadam would probably not warrant a change in assessment category.

\section{Remarks}

The type material was collected during the AMNH 1933-1934 Expedition to the then colonies of Kenya and Uganda led by Mr. Arthur Loveridge, a Fellow of the Guggenheim Memorial Foundation. Potamon (Geothelphusa) amalerensis Rathbun, 1935 stat. rev., is redescribed here as the valid species 
Potamonautes amalerensis stat. rev., because Bott (1955) erroneously treated this taxon as a junior synonym of Potamonautes (Rotundopotamonautes) didieri (Rathbun, 1904) from the D.R. Congo (Cumberlidge \& Clark 2012). This opinion of Bott (1955) is further undermined by the fact that he re-described $P$. didieri based on a non-type museum specimen from 'Ethiopia' using photographs of the carapace and illustrations of the gonopods of this (unidentified) specimen (ZSM, CW $37 \mathrm{~mm}$ ). As a result, a number of subsequent authors (Cumberlidge 1997, 1998; $\mathrm{Ng}$ et al. 2008; Cumberlidge et al. 2009) did not accept the opinion of Bott (1955), and recognized P. didieri and P. amalerensis stat. rev. as valid Potamonautes species. Illustrations and photographs of the holotype of $P$. amalerensis stat. rev.

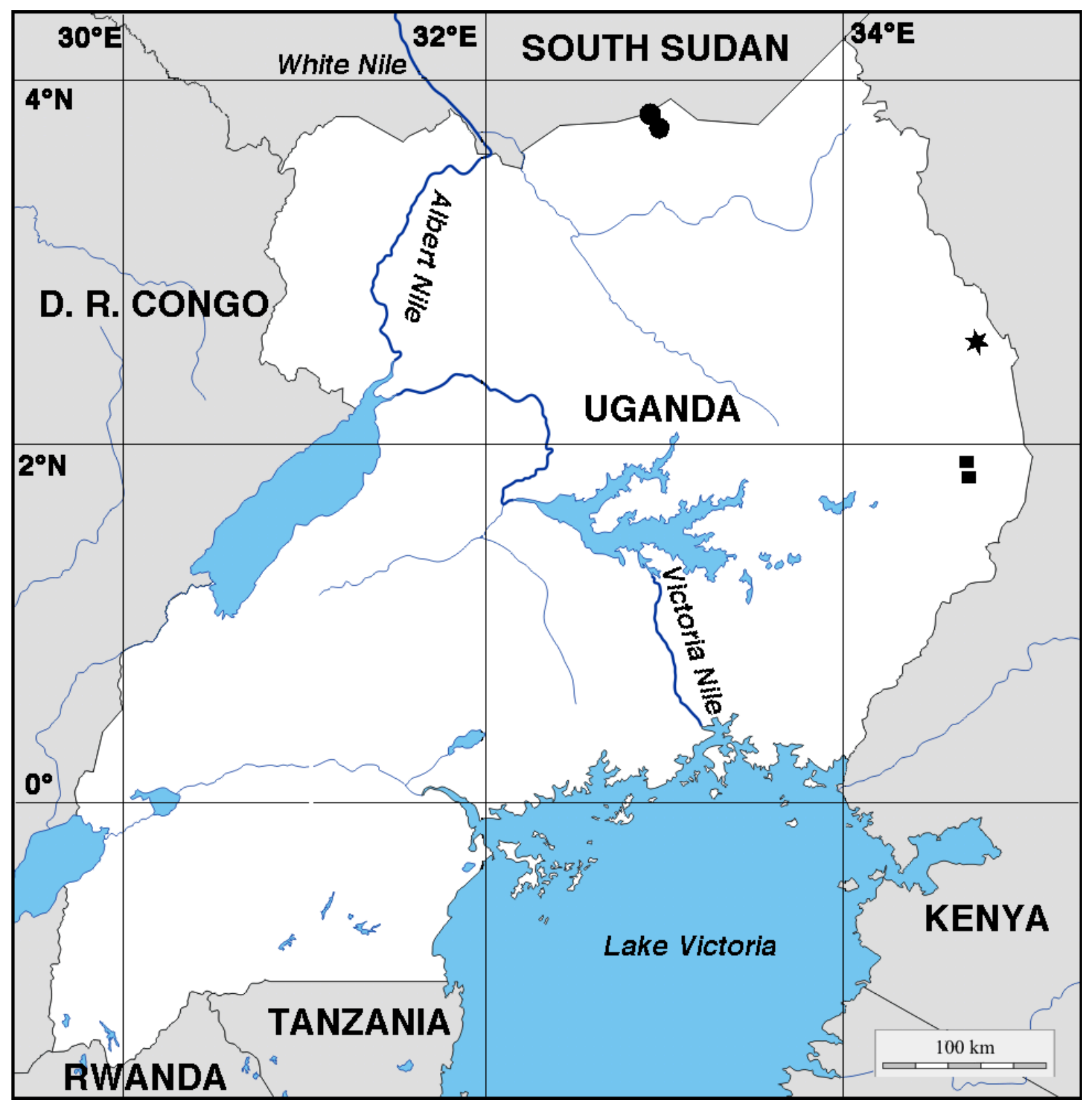

Fig. 8. Distribution map showing the known localities of Potamonautes imatongensis sp. nov. (black circles, not shown to scale), Potamonautes morotoensis sp. nov. (black star, not shown to scale) and Potamonautes amalerensis (Rathbun, 1935) stat. rev. (black squares, not shown to scale) in Uganda. East Africa. For exact localities see text. 
were provided by Rathbun (1935: 25, plate 2) as Potamon (Geothelphusa) amalerensis stat. rev. and by Chace (1942: 204, fig. 8) as Potamon amalerensis stat. rev.

Potamonautes amalerensis stat. rev. is superficially similar to several other species of African freshwater crabs in that they share the following characters: a small body size at maturity (beginning at $\mathrm{CW} 18 \mathrm{~mm}$ ); a complete postfrontal crest; completely reduced or absent exorbital and epibranchial teeth; smooth anterolateral margins immediately behind each epibranchial tooth; a third maxilliped ischium that lacks a visible sulcus; a cheliped merus with a strong and pointed distal meral tooth; and a slim, elongated, arched dactylus of the male major cheliped that when closed encloses either a wide oval interspace or a long narrow interspace. For comparisons of $P$. amalerensis stat. rev. with $P$. morotoensis sp. nov. and P. imatongensis sp. nov. see above.

\section{Acknowledgements}

We would like to acknowledge support from an NMU Faculty Grant Award, and the contributions of NMU biology student Wesley S. Bos for assisting in part of this work.

\section{References}

Barnley G.R. \& Prentice M.A. 1958. Simulium neavei in Uganda. East African Medical Journal 35: 475. Bott R. 1955. Die Süßwasserkrabben von Afrika und ihre Stammesgeschichte. Annales du Musée Royal du Congo belge 1 (3): 209-352.

Chace F.A. 1942. Scientific results of a fourth expedition to forested areas in eastern Africa, III: Decapod Crustacea. Bulletin of the Museum of Comparative Zoology at Harvard College 91 (3): 185-233. available from http://biodiversitylibrary.org/page/4788521 [accessed 18 Feb. 2016]

Crosskey R.W. 1990. The Natural History of Blackflies. John Wiley \& Sons, London. http://dx.doi. org $/ 10.1017 / \mathrm{s} 0007485300053323$

Cumberlidge N. 1997. The African and Madagascan freshwater crabs in the Museum of Natural History, Vienna (Crustacea: Decapoda: Brachyura: Potamoidea). Annalen des Naturhistorischen Museums in Wien 99B: 571-589.

Cumberlidge N. 1998. The African and Madagascan freshwater crabs in the Zoologische Staatssammlung, Munich (Crustacea: Decapoda: Brachyura: Potamoidea). Spixiana 21 (3): 193-214.

Cumberlidge N. 1999. The Freshwater Crabs of West Africa, Family Potamonautidae. Faune et Flore tropicales 35, IRD, Paris.

Cumberlidge N. 2008. Potamonautes amalerensis. The IUCN Red List of Threatened Species. Version 2014.3. Available at www.iucnredlist.org [accessed on 24 Feb. 2015].

Cumberlidge N. \& Clark P.F. 2010. Two new species of freshwater crabs from Mt. Elgon, East Africa (Brachyura: Potamoidea: Potamonautidae) with a redescription of Potamonautes niloticus (A. MilneEdwards, 1887) and notes on their natural history. Journal of Natural History 44: 1807-1829. http:// dx.doi.org/10.1080/00222931003678792

Cumberlidge N. \& Clark P.F. 2012. The freshwater crabs of Ethiopia, northeastern Africa, with the description of a new Potamonautes cave species (Brachyura: Potamonautidae). Contributions to Zoology 81: $235-251$.

Cumberlidge N., Ng P.K.L., Yeo D.C.J., Magalhaes C., Campos M.R., Alvarez F., Naruse T., Daniels S.R., Esser L.J., Attipoe F.Y.K., Clotilde-Ba F.-L., Darwall W., McIvor A., Baillie J.E.M., Collen B. \& Ram M. 2009. Freshwater crabs and the biodiversity crisis: Importance, threats, status, and conservation challenges. Biological Conservation 142 (8): 1665-1673.http://dx.doi.org/10.1016/j.biocon.2009.02.038 
Cumberlidge N. \& Meyer K.S. 2011. The freshwater crabs of Lake Kivu (Crustacea: Decapoda: Brachyura: Potamonautidae). Journal of Natural History 45 (29-32): 1835-1857. http://dx.doi.org/10. $\underline{1080 / 00222933.2011 .562618}$

Hynes H.B.N., Williams T.R. \& Kershaw W.E. 1961. Freshwater crabs and Simulium neavei in East Africa. I. - Preliminary observations made on the slopes of Mt. Elgon in December, 1960, and January, 1961. Annals of Tropical Medicine and Parasitology 55: 197-201.

IUCN 2003. IUCN Species Survival Commission (2012) IUCN Red List categories and criteria. Version 3.1, 2nd edn, IUCN, Gland, Switzerland.

McMahon J.P., Highton R.B. \& Goiny H. 1958. The eradication of Simulium neavei from Kenya. Bulletin of the World Health Organisation 19: 75-107.

Ng P.K.L., Guinot D. \& Davie P. 2008. Systema Brachyuorum: Part I. An annotated checklist of extant Brachyuran crabs of the world. Raffles Bulletin of Zoology Supplement 17: 1-286.

Rathbun M.J. 1921. The brachyuran crabs collected by the American Museum Congo Exepedition, 1909-1915. Bulletin of the American Museum of Natural History 43: 379-468. http://biodiversitylibrary. org/page/26896893

Rathbun M.J. 1935. Scientific Results of an Expedition to Rain Forest Regions in Eastern Africa. 2. Crustacea. Bulletin of the Museum of Comparative Zoology at Harvard College 79: 23-28. http:// biodiversitylibrary.org/page/2828646

Williams T.R. 1968. The taxonomy of the East African river crabs and their association with the Simulium neavei complex. Transactions of the Royal Society of Tropical Medicine and Hygiene 62 (1): 29-34. http://dx.doi.org/10.1016/0035-9203(68)90027-8

Williams T.R. 1991. Freshwater crabs and Simulium neavei in East Africa. III. morphological variation in Potamonautes loveni (Decapoda: Potamidae). Transactions of the Royal Society of Tropical Medicine and Hygiene 85: 181-188.

Williams T.R., Hynes H.B.N. \& Kershaw W.E. 1964. Freshwater crabs and Simulium neavei in East Africa. II. Further observations made during a second visit to East Africa in February-April 1962. Annals of Tropical Medicine and Parasitology 58: 159-168.

Manuscript received: 13 August 2015

Manuscript accepted: 17 November 2015

Published on: 17 March 2016

Topic editor: Rudy Jocqué

Desk editor: Kristiaan Hoedemakers

Printed versions of all papers are also deposited in the libraries of the institutes that are members of the EJT consortium: Muséum national d'Histoire naturelle, Paris, France; Botanic Garden Meise, Belgium; Royal Museum for Central Africa, Tervuren, Belgium; Natural History Museum, London, United Kingdom; Royal Belgian Institute of Natural Sciences, Brussels, Belgium; Natural History Museum of Denmark, Copenhagen, Denmark. 